\title{
Structural Systems for Tallest Buildings and Their Applications
}

\author{
K. Moon \\ School of Architecture, Yale University, New Haven, CT 06511, USA
}

\begin{abstract}
Tall buildings that began from about 10-story tall office towers in the late 19th century have evolved into mixed-use megatall towers over 150 stories. Structural systems have been one of the most fundamental technologies for the dramatic developments of tall buildings. This paper presents structural systems employed for the world's tallest buildings of different periods since the emergence of supertall buildings in the 1930s and their applications for contemporary supertall and megatall buildings.
\end{abstract}

\section{Introduction}

Tall buildings emerged in the late 19th century in New York and Chicago. Two critical technologies for the prototype of early tall buildings were elevators and skeletal structures. In the Home Insurance Building of 1885 in Chicago, both passenger elevators and iron/steel skeletal structures were employed for the first time for a 10-story office building. Since then, the primitive skeletal structure evolved further into moment resisting frames often in combination with lateral wind bracings. With the two essential technologies for tall buildings, the new building type developed rapidly.

From around the turn of the century, the height race began starting from the Park Row Building in New York which had already reached 30 stories in 1899 as the symbolic power of tall buildings began to be recognized. The threshold height of supertall buildings, $300 \mathrm{~m}$, was first reached by the $319 \mathrm{~m}$ tall Chrysler Building of 1930 in New York, and the height race was culminated with the $381 \mathrm{~m}$ tall Empire State Building of 1931 also in New York.

During the late 1960s and 1970s, new structural concepts of various tubular systems were developed, and this produced supertall buildings of more efficient and economical structures. Notable examples at that time include the 343 m tall John Hancock Center (now called 875 North Michigan Avenue) of 1969 in Chicago, the demolished $417 \mathrm{~m}$ tall One World Trade Center of 1972 and $415 \mathrm{~m}$ tall Two World Trade Center of 1973 both in New York as twin towers, and the $442 \mathrm{~m}$ tall Sears Tower (now called Willis Tower) of 1974 in Chicago.

Toward the end of the $20^{\text {th }}$ century, the region of major tall building developments moved from the U.S. to Asian countries, which reflects their rapid economic growth. The title of the tallest in the world was also taken by twin supertalls in Asia for the first time. The $452 \mathrm{~m}$ tall Petronas Towers of 1998 in Kuala Lumpur exceeded the architectural height of the Sears Tower which still held the title of the tallest occupied floor then. In 2004, the $508 \mathrm{~m}$ tall Taipei 101 in Taipei finally eclipsed the both architectural and occupied heights of the Sears Tower. 
More recently in the $21^{\text {st }}$ century, the Middle East also jumped into the height race and the $828 \mathrm{~m}$ tall Burj Khalifa of 2010 in Dubai took the title with a very large margin. Further, the Jeddah Tower at its expected height over $1 \mathrm{~km}$ in Jeddah is under construction at present to surpass the Burj Khalifa soon. Based on the oil wealth, the Middle East has rapidly become a new region for tall, supertall and megatall (over $600 \mathrm{~m}$ ) buildings.

Structural systems have been one the most fundamental technologies for tall buildings and evolving fast to meet ever increasing various complex requirements. This paper presents structural systems employed for the world's tallest buildings of different periods since the Empire State Building and their applications for contemporary supertall and megatall buildings.

\section{Structural Systems for Tallest Buildings}

The moment resisting frame with lateral wind bracings around the building's core was the predominantly used structural system for tall buildings including the Empire State Building before the development of the more efficient tubular system by Fazlur Khan in the 1960s. The structural steel use for the Empire State Building was $42.2 \mathrm{psf}\left(206 \mathrm{~kg} / \mathrm{m}^{2}\right)$. More steel was used for the Empire State Building than the supertalls of tubular systems built decades later. Table 1 shows structural systems used for the tallest buildings in the world during different periods since the Empire State Building that held the tallest title for over 40 years.

Table 1: Structural systems for the tallest buildings in the world since 1931

\begin{tabular}{|l|l|l|r|r|r|l|}
\hline Building & City & $\begin{array}{l}\text { Tallest } \\
\text { Period }\end{array}$ & $\begin{array}{r}\text { Architectural } \\
\text { Height }(\mathrm{m})\end{array}$ & $\begin{array}{r}\text { Occupied } \\
\text { Height }(\mathrm{m})\end{array}$ & Story & $\begin{array}{l}\text { Structural } \\
\text { System }\end{array}$ \\
\hline \hline $\begin{array}{l}\text { Empire State } \\
\text { Building }\end{array}$ & $\begin{array}{l}\text { New } \\
\text { York }\end{array}$ & $\begin{array}{l}1931- \\
1972\end{array}$ & 381 & 373 & 102 & $\begin{array}{l}\text { Braced Moment } \\
\text { Resisting Frame }\end{array}$ \\
\hline $\begin{array}{l}\text { One World Trade } \\
\text { Center, Demolished }\end{array}$ & $\begin{array}{l}\text { New } \\
\text { York }\end{array}$ & $\begin{array}{l}1972- \\
1974\end{array}$ & 417 & 413 & 110 & Framed Tube \\
\hline $\begin{array}{l}\text { Sears Tower (now } \\
\text { Willis Tower) }\end{array}$ & Chicago & $\begin{array}{l}1974- \\
1998\end{array}$ & 442 & 413 & 108 & Bundled Tube \\
\hline Petronas Towers & $\begin{array}{l}\text { Kuala } \\
\text { Lumpur }\end{array}$ & $\begin{array}{l}1998- \\
2004\end{array}$ & 452 & 375 & 88 & Tube-in-Tube \\
\hline Taipei 101 & Taipei & $\begin{array}{l}2004- \\
2010\end{array}$ & 508 & 436 & 101 & Core-Outrigger \\
\hline Burj Khalifa & Dubai & $\begin{array}{l}2010- \\
\text { present }\end{array}$ & 828 & 585 & 163 & Buttressed Core \\
\hline
\end{tabular}

The framed tube, as the firstly conceived tube system, was employed for the new tallest building in steel, the demolished One World Trade Center that initiated the new supertall era 41 years after the construction of the Empire State Building. Only two years after the completion of the One World Trade Center, the $25 \mathrm{~m}$ taller Sears Tower was built with the bundled tube system which reduced the shear-lag induced inefficiency of the framed tube. The steel uses for the One World Trade Center and Sears Tower were 37.0 psf (181 $\left.\mathrm{kg} / \mathrm{m}^{2}\right)$ and $33.0 \mathrm{psf}\left(161 \mathrm{~kg} / \mathrm{m}^{2}\right)$ respectively. These developments of tubular systems resulted in more efficient tallest building structures compared to the Empire State Building. Another important tube system is the braced tube employed for the $344 \mathrm{~m}$ tall John Hancock Center of 1969 in Chicago. This building used only $29.7 \mathrm{psf}\left(145 \mathrm{~kg} / \mathrm{m}^{2}\right)$ structural steel despite its greater height-to-width aspect ratio of 7.9 compared to the One World Trade Center's 6.9 and Sears Tower's 6.4 (Schueller, 1990). The braced tube, more efficient 
than the framed or bundled tube in general, is, in fact, one of the most efficient structural systems for tall buildings. Interestingly, however, it was never used for the tallest building of any period.

Since the completion of the Sears Tower in 1974 no supertall buildings were built in any place of the world until the construction of the $367 \mathrm{~m}$ tall Bank of China of 1990 in Hong Kong. This is about the time when the most active tall building development region moved from the U.S. to Asian countries. Since the 1990s, many tall and supertall buildings have been built in Asia including the Petronas Towers that exceeded the architectural height of the Sears Tower by $10 \mathrm{~m}$. However, one of the most fundamental architectural design criteria is to provide occupiable spaces for people, and it is noted that the tallest building in that regard was still Sears Tower with its tallest occupied height $38 \mathrm{~m}$ taller than that of the Petronas Towers. Table 1 also shows the comparison between the architectural and occupied heights. The world's tallest height of the Petronas Towers was accomplished by designing and constructing the spires as integral parts of the main structures of the towers.

In terms of structural materials, unlike all the other previous tallest buildings structured with steel, the Petronas Towers were built with reinforced concrete and steel resulting in composite structures. Since the beginning of the Asian era of tall buildings, reinforced concrete alone or in combination with steel has widely been used for structural systems of tall buildings globally. The primary lateral load resisting system for the Petronas Towers is the tubein-tube composed of the reinforced concrete core and perimeter framed tube. Due to the diversity in materials use, direct efficiency comparisons between tall building structures have become inappropriate. In 2004, the Taipei 101 in Taipei finally reached the height of $0.5 \mathrm{~km}$ for the first time. With its tallest occupied height at $438 \mathrm{~m}$, it also exceeded the tallest occupied height of the Sears Tower by $20 \mathrm{~m}$. The core-outrigger system, which became very popular from the late 1990s, was employed for the Taipei 101 using reinforced concrete and steel, resulting in a composite structure.

In addition to Asia, Middle East has even more recently become one of the most active regions of tall building developments. Dubai alone with its 37 supertall buildings either completed or under construction at present is the city having the largest number of supertalls in the world. With its height of $828 \mathrm{~m}$, it exceeded the height of the previous tallest Taipei 101 by a significant margin of $320 \mathrm{~m}$. The Y-shaped plan form-integrated reinforced concrete "buttressed core" system was employed for the Burj Khalifa to reach the unprecedented enormous height.

\section{Applications of Structural Systems for Tallest Buildings}

\subsection{Tubular Structures}

Framed and bundled tube systems produced the tallest buildings in the 1970s. However, their uses in their original forms have been somewhat limited in contemporary tall buildings due to the systems' tendency to substantially influence architectural design. Nonetheless, due to their inherent structural efficiency, tubular structures are continuously used especially in their modified forms or combined forms with other systems for today's exceedingly tall buildings. 
Among various tubular structures, the braced tube system with perimeter diagonals is generally most efficient because it carries both lateral shear forces and overturning moments primarily by axial actions of the perimeter tube members. Conventional braced tubes are typically composed of evenly spaced multiple columns on each face of the building. However, the system's structural efficiency can further be increased by rearranging the perimeter columns to result in corner megacolumns. By placing corner megacolumns, the system's performance in resisting overturning moments can be maximized (Figure 1). These modified braced tube systems have been employed for contemporary supertall buildings such as the $597 \mathrm{~m}$ tall Goldin Finance 117 in Tianjin and $528 \mathrm{~m}$ Citic Tower (formerly known as China Zun) in Beijing. The both buildings are currently under construction.
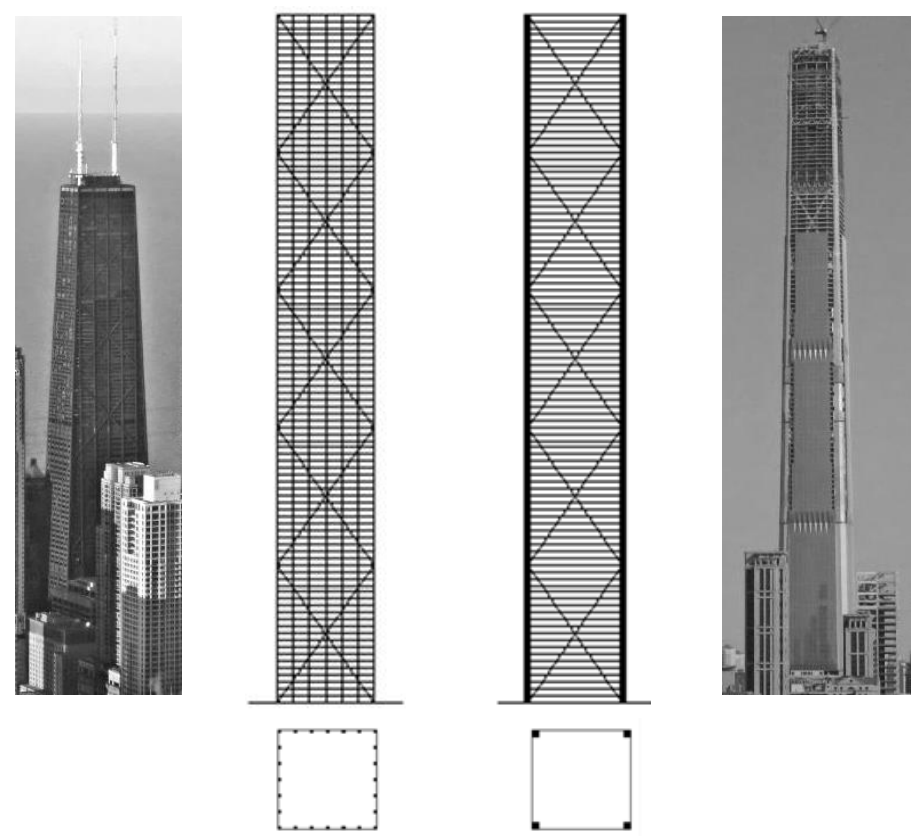

Fig. 1. Braced tube structures with evenly spaced perimeter columns vs. corner megacolumns (with small gravity columns between them) employed in the John Hancock Center and Goldin Finance 117 respectively.

\subsection{Core-Outrigger Structures}

Early uses of the core-outrigger system can be found in tall buildings of the 1960s. However, the system was employed for tall buildings up to only about 60 stories at that time. The application of the core-outrigger system for supertalls such as the $421 \mathrm{~m}$ tall Jin Mao Tower in Shanghai began from the late 1990s. Since then, core-outrigger structures have been used for much taller supertall and megatall buildings including the $508 \mathrm{~m}$ tall Taipei 101 in Taipei, $555 \mathrm{~m}$ tall Lotte World Tower in Seoul (Figure 2), and $632 \mathrm{~m}$ tall Shanghai Tower in Shanghai to name just but a few. Furthermore, the system has already been applied to an even taller building currently on hold, the 729 $m$ tall Suzhou Zhongnan Center in Suzhou. 


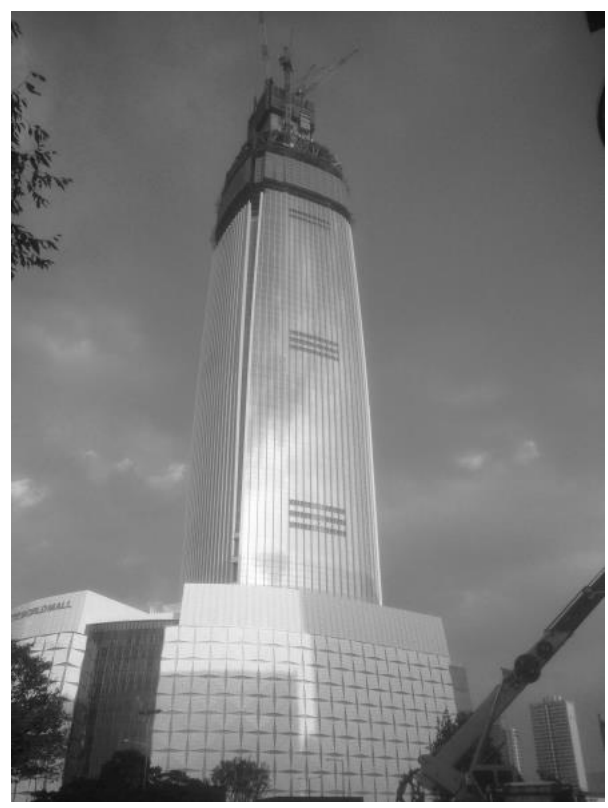

Fig. 2. Lotte World Tower during construction.

Different from the tubular structures that truly use the entire building width as their structural depth against lateral loads, the performance of the coreoutrigger system still significantly relies on the interior core whose structural depth is much smaller than the building width (Figure 3). Therefore, the structural efficiency of the core-outrigger system cannot exceed that of more efficient tube type structures with large perimeter diagonals such as braced tubes and diagrids. However, a very important reason why the core-outrigger system is used for very tall buildings sometimes even taller than those tube type structures is that it is architecturally more flexible in façade design because it requires only a limited number of perimeter columns.
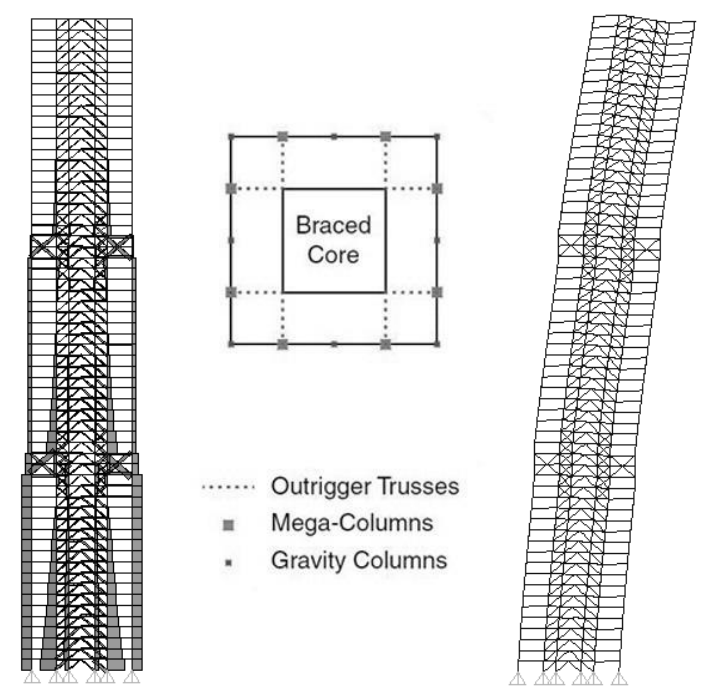

Fig. 3. Axial force diagram and deformed shape of core-outrigger system subjected to wind loads. 


\subsection{Buttressed Core Structures}

Since the development of the buttressed core system for the $828 \mathrm{~m}$ tall Burj Khalifa, the structural concept has been employed for a limited number of extremely tall buildings including the Jeddah Tower, which will finally become the first tallest building exceeding the height of $1 \mathrm{~km}$. These megatall buildings have three wings in combination with tapered forms for better architectural and structural performances. The central structural core is extended as shears walls into the architectural spaces of the three wings in these buildings.

The extended shear walls from the central core to form the buttressed core structures are terminated with thickened flange walls perpendicular to the extended shear walls. Therefore, the system can be conceived as an enormous vertical wide flange beam with Y-shaped cross section subjected to lateral loads. The extended shear walls to the wing spaces are stiffened by additional shear walls called "fin walls" perpendicular to them with outriggers or through deep coupling beams as in the Burj Khalifa and Jeddah Tower respectively. These fin walls perform like web stiffeners in deep wide flange beams.
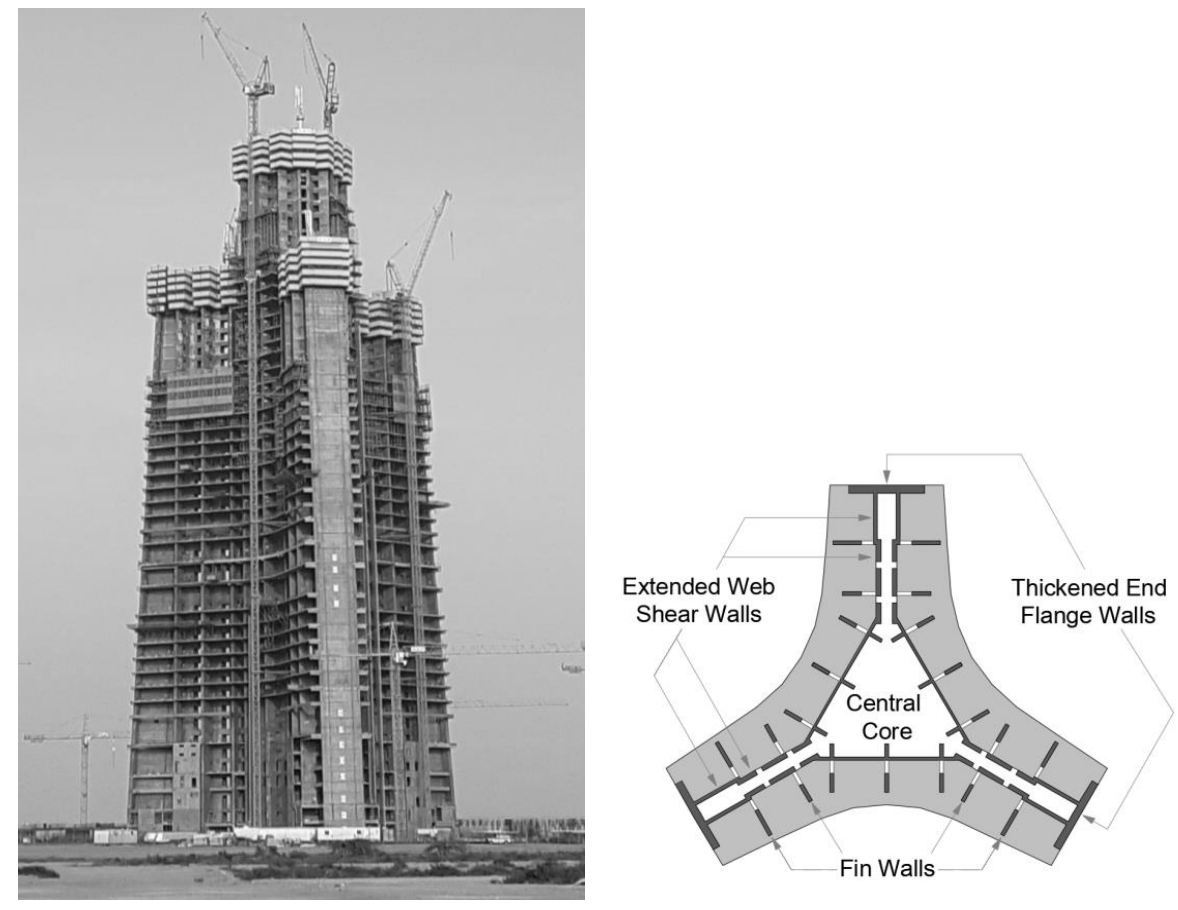

Fig. 4. Axial force diagram and deformed shape of core-outrigger system subjected to wind loads.

Though the architecture-integrated buttressed core system provides efficient structures with increased structural depths, flexibility in interior space use is limited to a large degree due to the specific forms required. However, within the overall mass of vertically extruded Y-shape, creating varied exterior building forms can be done without much difficulty as the extended shear walls can be terminated in various different ways without transfer structures. They are terminated to create spirally stepping or smoothly tapering forms in the Burj Khalifa and Jeddah Tower respectively. These 
tapered forms provide superior structural performances in terms of not only static but also dynamic wind responses by disturbing organized vortex shedding over the building height.

\section{Conclusions}

This paper has reviewed structural systems for the tallest buildings of different periods and their applications for contemporary supertall and megatall buildings. While the exceedingly tall buildings and their structural systems presented in this paper are certainly astonishing achievements, developing technologies and designs further beyond what we have reached so far is still essential for better performing and more sustainable sky-high built environments.

\section{References}

Ali, M. M., 2001. Art of the Skyscraper: The Genius of Fazlur Khan, Rizzoli International Publications, New York, NY.

Ali, M. M. and Moon, K., 2007. "Structural Developments in Tall Buildings: Current Trends and Future Prospects," Architectural Science Review Journal, Vol. 50.3, pp. 205-223.

Ali, M. M. and Moon, K., 2018. "Advances in Structural Systems for Tall Buildings: Emerging Developments for Contemporary Urban Giants," Buildings, 2018, 8(8), 104; doi: 10.3390/buildings8080104.

Arup., 2018. Arup's Tall Buildings in Asia: Stories behind the Storeys. Lodon and New York: Routledge.

Council on Tall Buildings and Urban Habitat (CTBUH), 2015. 100 of the World's Tallest Buildings. Images Publishing Group, Mulgrave.

Council on Tall Buildings and Urban Habitat, 2015. Tall Buildings of China. Images Publishing Group, Mulgrave.

Choi, H.S., Ho, G., Joseph, L and Mathias, N, 2016. Outrigger Design for High-Rise Buildings: An output of the CTBUH Outrigger Working Group, Images Publishing Group, Mulgrave.

Landau, S. and Condit, C., 1996. Rise of the New York Skyscraper, 1865-1913. New Haven: Yale University Press.

Leslie, T., 2013. Chicago Scrapers 1871-1934. Urbana, Chicago and Springfield: University of Illinois Press.

Moon, K., 2016. "Outrigger Structures for Complex-Shaped Tall Buildings," International Journal of Hi-Rise Buildings. Vol.5-1, pp 13-20.

Schueller, W., 1990. The Vertical Structure, Van Nostrand Reinhold, New York, NY.

Smith, B. and Coull, A., 1991. Tall Building Structures: Analysis and Design. Wiley, New York, NY.

Tamboli, A.R. (ed.), 2014. Tall and Supertall Buildings: Planning and Design, McGraw-Hill, New York, NY.

Weismantle, P., 2018. "Challenges in the Architectural Technical design of the New Generation of Supertall Buildings," International Journal of Hi-Rise Buildings. Vol.7-1, pp 85-93. 